\title{
Physicochemical characterization and evaluation of in vitro and in vivo toxicity of goldenberry extract nanoemulsion
}

\author{
Suelen Santos da Silva ${ }^{1}$ Maiara Taís Bazana ${ }^{1}$ Cassandra de Deus $^{1}$ Marina Lopes Machado ${ }^{2}$ \\ Larissa Marafiga Cordeiro ${ }^{2}$ Félix Alexandre Antunes Soares ${ }^{2}$ Daniele Rubert Nogueira Libreloto ${ }^{3}$ \\ Clarice Madalena Bueno Rolim ${ }^{3}$ Cristiano Ragagnin de Menezes $^{1}$ (iD) Cristiane Franco Codevilla ${ }^{*}($ iD
}

${ }^{1}$ Departamento de Tecnologia e Ciência dos Alimentos, Universidade Federal de Santa Maria (UFSM), 97105-900, Santa Maria, RS, Brasil. E-mail: cristianefc@hotmail.com. *Corresponding author.

${ }^{2}$ Departamento de Bioquímica Toxicológica, Universidade Federal de Santa Maria (UFSM), Santa Maria, RS, Brasil.

${ }^{3}$ Departamento de Farmácia Industrial, Universidade Federal de Santa Maria (UFSM), Santa Maria, RS, Brasil.

ABSTRACT: Oil-in-water $(O / W)$ nanoemulsion containing goldenberry extract was elaborated using a high-energy ultrasonic bath method. Physicochemical characterization of the formulation was carried out by determining $\mathrm{pH}$, mean droplet diameter, polydispersity index (PDI) and zeta potential. Nanoemulsion toxicity was assessed using in vitro assays with tumor and non-tumor cell lines, and in vivo using Caenorhabditis elegans. The $\mathrm{pH}$ of the nanoemulsion was 3.84, the mean droplet diameter was $268 \pm 7 \mathrm{~nm}$, PDI 0.113 and zeta potential $-13.94 \mathrm{mV}$. Results of the cytotoxicity assays employing non-tumor cells indicated that the extract associated or not with nanoemulsion maintained cell viability at different concentrations tested. In the assays using tumor lineage, it is observed that the nanoemulsion containing the extract had higher antitumor activity than the free extract. As for the in vivo tests, there was no change in the survival rate of the worms.

Key words: Physalis peruviana, nanoemulsion, citotoxicity, C. elegans.

\section{Caracterização físico-química e avaliação da toxicidade in vitro e in vivo de nanoemulsão contendo extrato de goldenberry}

RESUMO: Nanoemulsão óleo/água (O/A) contendo extrato de goldenberry foi elaborada utilizando método de banho ultrassônico de alta energia. A caracterização fisico-química da formulação foi realizada pela determinação do $\mathrm{pH}$, diâmetro médio de gotas, indice de polidispersão (PDI) e potencial zeta. A toxicidade das nanoemulsões foi avaliada utilizando ensaios in vitro com linhas celulares tumorais e não tumorais e in vivo utilizando Caenorhabditis elegans. $O$ pH da nanoemulsão foi de 3,84, o diâmetro médio das gotículas foi de $268 \pm 7$ nm, PDI 0,113 e o potencial zeta $-13,94 \mathrm{mV}$. Os resultados dos ensaios de citotoxicidade empregando células não tumorais indicaram que o extrato associado ou não à nanoemulsão manteve a viabilidade celular em diferentes concentrações testadas. Nos ensaios, utilizando linhagem tumoral, observou-se que a nanoemulsão contendo o extrato apresentou maior atividade antitumoral do que o extrato livre. Quanto aos testes in vivo, não houve mudança na taxa de sobrevivência dos vermes.

Palavras-chave: Physalis peruviana, nanoemulsão, citotoxicidade, C. elegans.

\section{INTRODUCTION}

Physalis peruviana belongs to the Solanaceae family, with approximately 120 species distributed throughout the tropical and subtropical regions of Asia, Africa and America. This fruit contains bioactive compounds with antioxidant, antibacterial, anti-inflammatory, antitumor and immunosuppressive properties (CODEVILLA et al., 2018). These compounds have low stability when exposed to high temperatures, light and oxygen. Thus, nanoemulsification is an option to protect these compounds from degradation and improve their distribution and bioavailability (EZHILARASI et al., 2013).

The oil-in-water $(\mathrm{O} / \mathrm{W})$ type nanoemulsion is a system that incorporates bioactive substances from a natural extract within the formulation (MASON et al., 2006). The size range of a nanoemulsion is between 10 and $1000 \mathrm{~nm}$, which confer much higher stability when compared to emulsions with larger droplet size (SOLANS et al., 2005).

The toxicity of nanoemulsions depends on the use of biodegradable and biocompatible excipients (BRUXEL et al., 2012). There may be some risks associated with the oral ingestion of 
nanoemulsions, such as their ability to alter the biological fate of bioactive components in the gastrointestinal tract and the potential toxicity of some of the components used in manufacturing (McCLEMENTS \& RAO, 2011).

Cell viability assays are currently used to investigate the toxicity of a nanomaterial (CONTI et al., 2012). In addition to the formulation components, the concentration, population and type of nanoparticles should be taken into account for toxicity. Properties such as size, shape and structure of nanoparticles were recognized as being related to cytotoxicity (MENDES et al., 2015).

Caenorhabditis elegans ( $C$. elegans), a free-living nematode, was first introduced as an animal model in 1965 by Sidney Brenner (RIDDLE et al., 1997). It is currently widely used as a model for in vivo studies, due to its ability to grow in Petri dishes, using Escherichia coli as the only food source, as well as its transparency and short life cycle (about 3 days at $\left.20^{\circ}\right)$ (GONZALEZ-MORAGAS et al., 2015). Another advantage of using this model is that the worms present many basic physiological processes that are conserved in relation to humans, allowing the correspondence and comparison of molecular mechanisms (KALETTA \& HENGARTNER, 2006).

In addition to the physicochemical characterization of the nanoemulsion containing goldenberry extract, this study aimed to verify its toxicity in in vitro and in vivo models.

\section{MATERIAL AND METHODS}

\section{Materials}

Goldenberry was obtained from Italbraz (Vacaria, Brazil) located at 28: 0: $44 \mathrm{~S}$ and 50:56:02 W. Ethanol and acetone were obtained from Dynamics (São Paulo, Brazil). Tween 80 was purchased from Synth (São Paulo, Brazil). Span 80 was purchased from Fluka (São Paulo, Brazil), Medium Chain Triglycerides (MCT) from Delaware (Porto Alegre, Brazil). MTT and DMSO were obtained from SigmaAldrich (St. Louis, USA). The wild type strain of C. elegans $\mathrm{N} 2$ (var. Bristol) was supplied by the Caenorhabditis Genetics Center (University of Minnesota, USA). The strain was maintained at 20 ${ }^{\circ} \mathrm{C}$ in nematode growth medium (NGM) on plates seeded with Escherichia coli OP50 as a food source (BRENNER, 1974).

\section{Extract preparation}

Hydroalcoholic extract of the fruit was prepared following the methodology developed by CODEVILLA et al. (2018). A mass of $15 \mathrm{~g}$ of fresh fruit was weighed, macerated and mixed with $25 \mathrm{~mL}$ of $60 \%(\mathrm{v} / \mathrm{v})$ ethanol and shaken $(200 \mathrm{rpm})$ for 2 hours, away from the light. The extract was then filtered into a polyamide (Sartorius Stedim Biotec) filter with $0.45 \mu \mathrm{m}$ porosity and stored under refrigeration. The concentration of physalis extract (PE) was $600 \mathrm{mg} \mathrm{mL}^{-1}$.

\section{Nanoemulsion preparation}

Formulations containing the extract and without extract (called white nanoemulsion) were elaborated following the methodology of BOUCHEMAL et al. (2004) with modifications. $0.077 \mathrm{~g}$ of Span $80,0.120 \mathrm{~g}$ of MCT, $20 \mathrm{mg} \mathrm{mL}^{-1}$ of goldenberry extract and $27 \mathrm{~mL}$ of acetone were used in the organic phase. After homogenization of this phase, it was sonicated for 10 minutes in an ultrasonic bath with $37 \mathrm{kHz}$ frequency and $40 \%$ amplitude (Elma ultrasonic, Germany), in the previously homogenized aqueous phase, consisting of $0.077 \mathrm{~g}$ Tween 80 and ultrapure water (Table 1). The organic solvent was removed by means of a rotary evaporator (Rotavapor R-210, Buchi, Switzerland) and the final volume of the formulation was fixed in $10 \mathrm{ml}$.

\section{Physicochemical characterization}

The mean droplet diameter and the polydispersity index (PDI) were determined by photon correlation spectrometry (ZetaSizer Nanoseries, Malvern, UK) with the dilution of an aliquot of the formulation in ultrapure water at a ratio of 1: 500. The zeta potential was measured by means of electrophoretic mobility, using the same equipment, with the nanoemulsion diluted in a solution of $10 \mathrm{mM} \mathrm{NaCl}$ at a ratio of 1: 500 . The $\mathrm{pH}$ analysis was performed using a $\mathrm{pH}$ meter (MS Tecnopon, Piracicaba, Brazil), previously

Table 1 - Composition of the nanoemulsion formulation.

\begin{tabular}{|c|c|c|}
\hline & $\begin{array}{l}\text { Goldenberry } \\
\text { nanoemulsion }\end{array}$ & $\begin{array}{c}\text { White } \\
\text { nanoemulsion }\end{array}$ \\
\hline \multicolumn{3}{|c|}{ 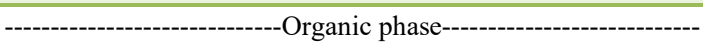 } \\
\hline Acetone & $27 \mathrm{~mL}$ & $27 \mathrm{~mL}$ \\
\hline Span $80^{\circledR}$ & $0.077 \mathrm{~g}$ & $0.077 \mathrm{~g}$ \\
\hline MCT & $0.120 \mathrm{~g}$ & $0.120 \mathrm{~g}$ \\
\hline Goldenberry extract & $20 \mathrm{mg} \mathrm{mL}^{-1}$ & - \\
\hline \multicolumn{3}{|c|}{ 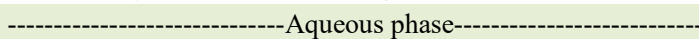 } \\
\hline Ultrapure water & $54 \mathrm{~mL}$ & $54 \mathrm{~mL}$ \\
\hline Tween $80^{\circledR}$ & $0.077 \mathrm{~g}$ & $0.077 \mathrm{~g}$ \\
\hline
\end{tabular}


calibrated, with direct immersion of the electrode in the formulation.

\section{Toxicity assessment} In vitro toxicity

The in vitro cytotoxicity of both extract of goldenberry and nanoemulsions, white (NB) and containing extract (NP), was measured using nontumor cell lines, murine (3T3) and human breast cancer cells (MCF-7). The 3T3 cells were seeded in 96-well plates with a density of $1 \times 10^{5}$ cells $\mathrm{mL}^{-1}$. After incubation for $24 \mathrm{~h}$ under $5 \% \mathrm{CO}_{2}$ at $37{ }^{\circ} \mathrm{C}$, the spent medium was replaced with $100 \mu \mathrm{L}$ of fresh medium containing extract, nanoemulsion containing extract and white nanoemulsion in the concentration range of $15.6-2000 \mu \mathrm{g} \mathrm{mL}^{-1}$ or with $100 \mu \mathrm{l}$ medium only for untreated control cells. After $24 \mathrm{~h}$ the medium was removed and $100 \mu \mathrm{l}$ of MTT solution (3- [4,5-dimethylthiazol-2-yl] -2,5-diphenyltetrazolium) $\left(0.5 \mathrm{mg} \mathrm{mL}^{-1}\right)$ were added. Plates were further incubated for $3 \mathrm{~h}$ after the medium was removed. Subsequently, $100 \mu \mathrm{L}$ of DMSO or a solution containing $50 \%$ absolute ethanol and $1 \%$ acetic acid in distilled water were added. The absorbance of the solutions was measured at $550 \mathrm{~nm}$ using the SpectraMax M2 microplate reader (Molecular Devices, CA, USA). Cytotoxicity of extract and nanoemulsions was expressed as percent viability over untreated control cells (the mean optical density of untreated cells was fixed at $100 \%$ viability).

\section{In vivo toxicity}

\section{Maintenance of animals}

C. elegans of strain N2 (wild type) was maintained on NGM plates (nematode growth medium) seeded with E. coli OP50 bacteria at $20{ }^{\circ} \mathrm{C}$. Worms in the young adult stage used in all the exposures were obtained by a synchronization process, which consists in exposing the pregnant worms to a lysis solution $(1 \% \mathrm{NaOCl}, 0.25 \mathrm{M} \mathrm{NaOH})$ to separate the eggs from the worms. After $14 \mathrm{~h}$, the eggs hatched and released the larvae of L1, which were added to the surface of NGM plates containing E. coli OP50, where they remained at $20^{\circ} \mathrm{C}$ until reaching young adult stage.

\section{Treatment}

The young adult stage of $C$. elegans were exposed to $0.5 ; 1.0$ and $2.0 \mathrm{mg} \mathrm{mL}^{-1}$ of EP, $\mathrm{NP}, \mathrm{NB}$ or vehicle for $2 \mathrm{~h}$ at $20{ }^{\circ} \mathrm{C}$. The EP was diluted in methanol (final concentration 1\%) and the NP and NB nanoemulsions were diluted in water. Treatments were performed with about 1000 worms per group in M9 buffer. After $2 \mathrm{~h}$ the worms were washed 3 times and transferred to NGM plates seeded with E. coli OP50. After $24 \mathrm{~h}$ at $20^{\circ} \mathrm{C}$, evaluations were performed.

\section{Survival test}

Survival assay was performed following the protocol previously described, with some modifications (VELASQUES et al., 2018). About 100 nematodes per group were evaluated for viability under a Nikon E200 microscope (Tokyo, Japan). Animals that reacted to a mechanical stimulus were classified as alive and non-responding animals were classified as dead. Analyses were performed in three independent trials. Results were expressed as percentage of survivors.

\section{Pharyngeal beat rate}

Number of pharyngeal beats over a range of $10 \mathrm{~s}$ (HUANG et al., 2004) was measured with a Nikon E200 microscope. The analyses were performed in three independent trials with ten worms per group. Results were expressed as pharyngeal beats/minute.

\section{Cycle of defecation test}

The defecation frequencies were performed by observing the duration between BPC steps (the contraction of the posterior muscle of the body) of three consecutive defects (MIGLIORI et al., 2011) in a Nikon E200 microscope. The analyses were performed in three independent trials with ten worms per group. Results were expressed as defecation cycle (s).

\section{Statistical analysis}

Statistical analyses were performed using GraphPad Prism ${ }^{\circledR}$ (Version 7.0, San Diego, CA). All experiments were independently replicated and the results were plotted as the mean \pm SEM of at least three individual experiments. Significance was assessed using One-way analysis of variance (ANOVA) followed by Bonferroni post hoc test. Values of $p<0.05$ were considered statistically significant.

\section{RESULTS AND DISCUSSION}

\section{Physicochemical characterization}

Nanoemulsions (Figure 1) had an average diameter of $268 \pm 7 \mathrm{~nm}$, a PDI of 0.113 and a zeta potential of - $13.94 \mathrm{mV}$. Polydispersity index, which provides information on the homogeneity of the 


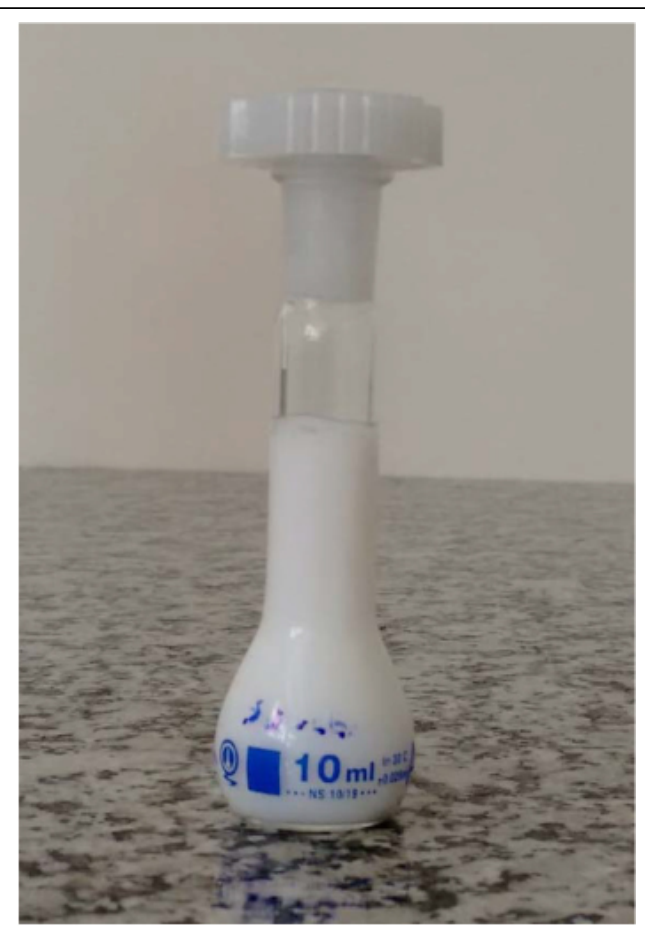

Figure 1 - Goldenberry nanoemulsion.

size distribution, was low $(<0.3)$, indicating the formation of monodisperse systems. The $\mathrm{pH}$ value provides information on the stability of the system, since its reduction may indicate the presence of free fatty acids in the formulation, resulting from the hydrolysis of the surfactant system (phospholipids) and the triglycerides of the oily nucleus. The hydroalcoholic extract of physalis had an acidic $\mathrm{pH}$ of 4.40 (CODEVILLA et al., 2018); consequently, the associated nanoemulsion also had an acidic $\mathrm{pH}$ of 3.84. The low $\mathrm{pH}$ value of the formulation is due to the phenolic acid content contained in the extract of goldenberry (ROCKENBACH et al., 2008).

The negative zeta potential of the nanoemulsion is due to the fact that polysorbate 80 (Tween 80) molecules adsorbed at the oil-water interface, because even though it is a nonionic surfactant, the presence of impurities, such as fatty acids, causes droplets of negative charge oil (SALVIA-TRUJILLO et al., 2015).

Nanoemulsions containing goldenberry extract and white were evaluated for 60 days, under refrigeration. The zeta potential decreased slightly at the end of the 60 days for both samples. However, this does not represent a lack of stability, since the size did not vary much and the polydispersity index remained below 0.3 . The $\mathrm{pH}$, which is also an important indicator of stability, showed no significant difference $(\mathrm{p}>0.05)$ over the 60 days.

Toxicity

In vitro evaluation

Because of its increased surface area, nanomaterials may have toxic effects on the body, which will not be apparent as in macro-sized materials. Thus, evaluation of cytotoxicity in nontumor cell lines is an important tool to predict the risk of bioactive compound absorption and potential toxicity (EISENBRAND et al., 2002).

It was observed that the viability of $3 \mathrm{~T} 3$ cells was reduced (Figure 2a) from 8 to $11 \%$ when exposed to PE. However, this reduction does not represent cytotoxicity of the extract to the cells, because for it to be considered toxic, the viability must be less than 75\% (ISO 10993-5) (WANG et al., 2015). CODEVILLA et al. (2018) also observed that there was no cytotoxicity of the hydroalcoholic extract of goldenberry. For NP, there was no reduction in cell viability, that is, it did not show cytotoxicity against $3 \mathrm{~T} 3$ cells (Figure 2a). The NB; however, influenced

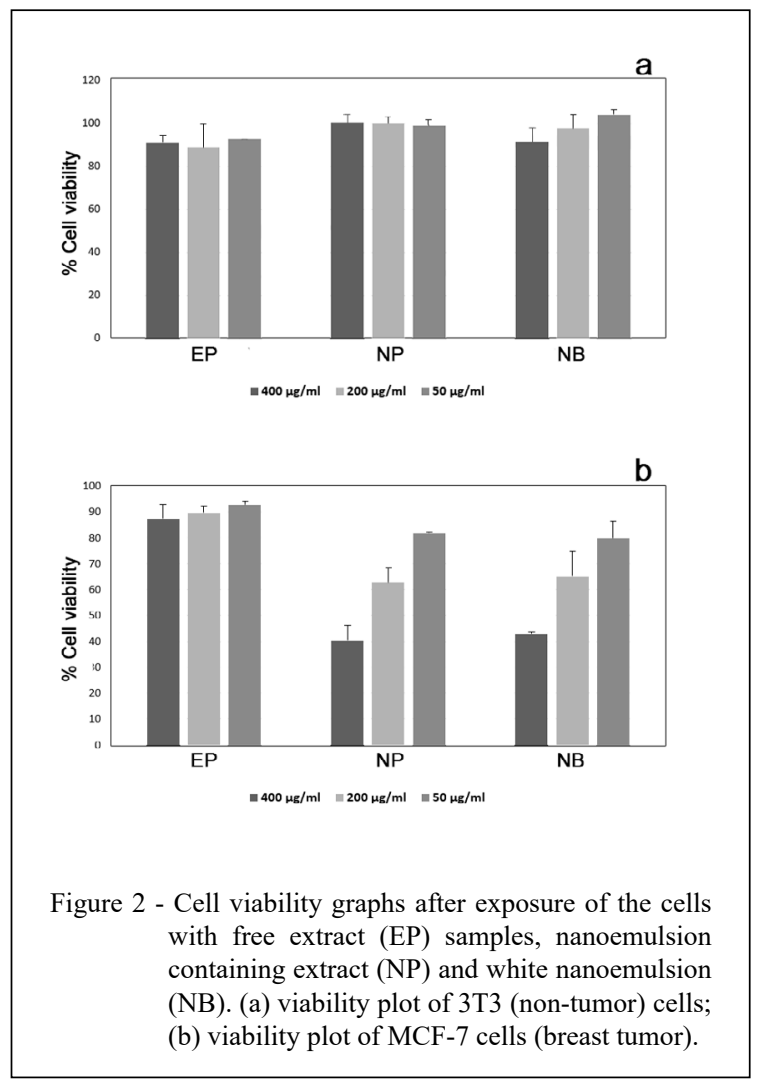


an approximately $9 \%$ reduction in growth when cells were exposed to $400 \mu \mathrm{g} \mathrm{mL}^{-1}$ of formulation (Figure 2a). However, results were above $80 \%$ cell viability, indicating that the formulations did not show cytotoxicity. Authors have highlighted the low cytotoxicity of nanoemulsions when associated with essential oils or plant extracts (MENDES et al, 2015).

For MCF-7 (tumor) cells, EP was not effective in inhibiting cell viability (Figure 2b), since it corroborates DEMIR et al. (2014) who reported the same result for the Physalis ethanolic extract $(80 \% \mathrm{v} / \mathrm{v})$. The NP and NB showed high inhibition values in the growth of these cells, as the concentration of the formulations increased. This may be related to what has already been described in the literature, namely that the components of the nanoemulsion have antioxidant power and also to the size of the droplet, which facilitates absorption by tumor cells (SHEKHAR, 2009). The presence of the nonionic surfactant, polysorbate 80 , has also been indicated as a substance that can cause toxicity in cell cultures; although, they are better tolerated than ionic surfactants, especially cationic surfactants. CONTI et al. (2012) observed that the toxicity of nanocapsules was due to the use of polysorbate 80 in the formulation.

\subsubsection{In vivo evaluation}

The in vivo toxicity of the formulations, using the $C$. elegans model, was evaluated by the survival rate (Figure 3), control of pharyngeal beats
(Figure 4), and defecation cycle (Figure 5). None of the EP, NP and NB concentrations altered the survival rate of the worms (Figure 3). This means that exposure to the samples did not stress the animals.

Subsequently, the pharyngeal beats were evaluated in order to verify whether the extracts and formulations alter feeding behavior. In this study, there was a small decrease in the pharyngeal beats of the worms (Figure 4), in relation to the control, in all samples evaluated. According to YOU et al. (2008), the worm ingests the food through the propulsive action of the pharynx and the speed of contraction of the pharynx is modulated by the presence of the food, by its quality, among others, showing that the decrease of the pharyngeal beats represents the decrease of the food intake of the worm. We believed that the reduction of the rate of pharyngeal beats is caused by the simple presence of the samples, since animals of the control group ate only M9.

In C. elegans, defecation is independent of temperature, but slow when food is scarce (the cycle increases to $80 \mathrm{~s}$ ) and may even be inhibited as food ceases and is only resumed when food is available (RIDDLE et al., 1997). The defecation cycle is considered a marker of toxicity due to changes that may occur in the permeability of the intestinal barrier (STEFANELLO et al., 2015). All the samples evaluated reduced the time of the defecation cycle (Figure 5), that is, the interval between cycles of defecation, probably to increase the excretion of undigested materials.

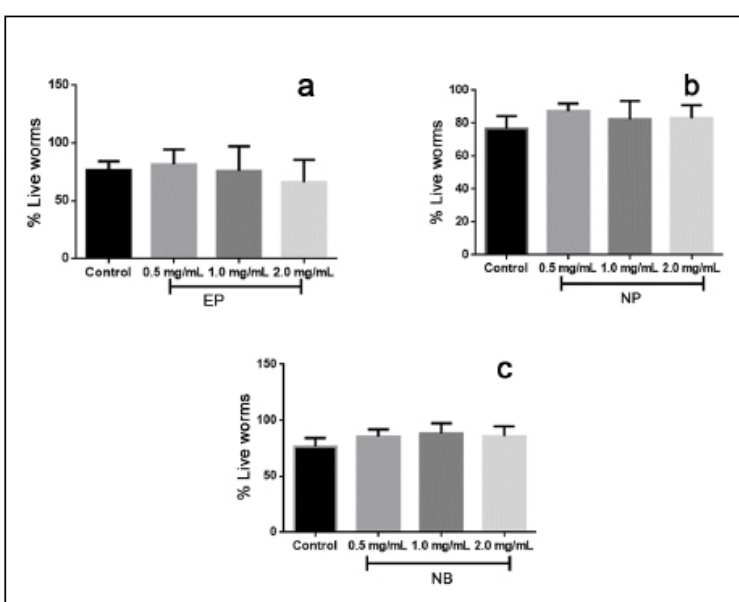

Figure 3 - Survival of young adult worms of strain N2 exposed to EP (a), NP (b) and NB (c) at different concentrations.

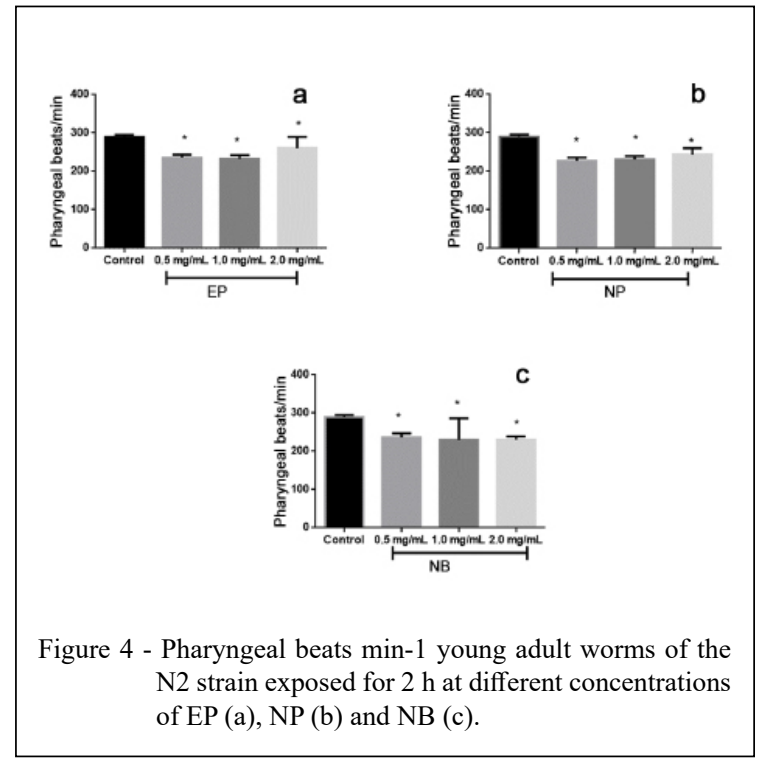

Ciência Rural, v.49, n.8, 2019. 


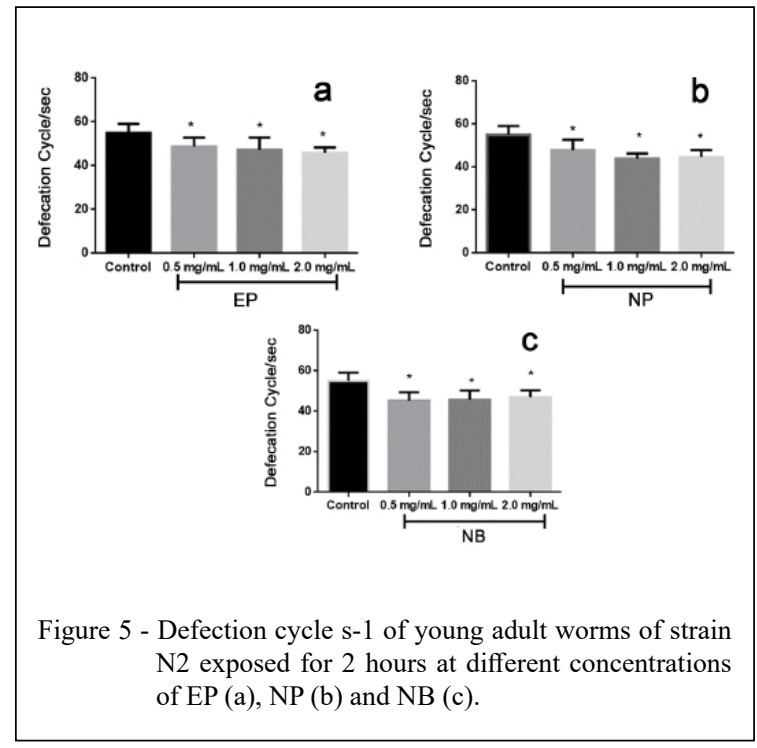

\section{CONCLUSION}

The nanoemulsion containing extract of goldenberry presented good physicochemical characteristics, desirable for a stable system. The in vitro and in vivo tests were instrumental in assessing possible toxicity, demonstrating that the extract and nanoemulsions showed no toxicity in a non-tumor cell line and the $C$. elegans model, respectively. The survival of C. elegans was not affected, whereas the rate of pharyngeal and defecation rate was reduced, confirming that worms absorb the formulations and that there are no toxic effects. However, both nanoemulsion containing extract and that containing no extract showed cytotoxicity in the in vitro assay for the tumor cell line, demonstrating possible antitumor activity of the formulations. Thus, a future application for this nanoemulsion can be studied and better developed.

\section{ACKNOWLEDGMENTS}

"This study was financed in part by the Coordenação de Aperfeiçoamento de Pessoal de Nível Superior - Brasil (CAPES) - Finance Code 001".

\section{DECLARATION OF CONFLICT OF INTERESTS}

The authors declare no conflict of interest. The founding sponsors had no role in the design of the study; in the collection, analyses, or interpretation of data; in the writing of the manuscript, and in the decision to publish the results.

\section{AUTHORS' CONTRIBUTIONS}

The authors contributed equally to the manuscript.

\section{REFERENCES}

BRENNER, S. The genetics of Caenorhabditis elegans. Genetics, v.77, n.1, p.71-94, 1974. Available from: <https://www.ncbi.nlm. nih.gov/pmc/articles/PMC1213120/>. Accessed: Mar. 03, 2017.

BRUXEL, F. et al. Nanoemulsões como sistemas de liberação parenteral de fármacos. Química Nova, v.35, n.9, p.1827-1840, 2012. Available from: $<$ http://www.scielo.br/scielo.php? script $=$ sci arttext\&pid=S0100-40422012000900023>. Accessed: Nov. 21, 2015. doi: 10.1590/S0100-40422012000900023.

BOUCHEMAL, K. et al. Nanoemulsion formulations using spontaneous emulsification: solvent, oil and surfactant optimization. International Journal of Pharmaceutics. v.280, n.1, p.241-251, 2004. Available from: $<$ https://linkinghub.elsevier. com/retrieve/pii/S0378517304003072>. Accessed: Jul. 23, 2015. doi: 10.1016/j.ijpharm.2004.05.016.

CODEVILlA, C. F. et al. Cytotoxicity and antioxidant of goldenberry extracts obtained with high intensity ultrasound. Ciência Rural, 48, CR-2017-0362.R2, 2018. Available from: $<$ http://www.scielo.br/scielo.php?script=sci arttext\&pid $=$ S0103-84782018000200752 $>$. Accessed: Sep. 02, 2018. doi: $10.1590 / 0103-8478 \mathrm{cr} 20170362$.

CONTI, D. S. et al. Propellant-based inhalers for the non-invasive delivery of genes via oral inhalation. Journal of Controlled Release, v.157, n.3, p.406-417, 2012. Available from: $<\mathrm{https}: / / \mathrm{www}$. sciencedirect. com/science/article/pii/S0168365911009436?via\%3Dihub>. Accessed: Apr. 13, 2016. doi: 10.1016/j.jconrel.2011.09.089.

DEMIR, T. et al. Antioxidant and cytotoxic activity of Physalis peruviana. Medicinal Plant Research. v.4, n.3, p.30-34, 2014. Available from: <http://biopublisher.ca/index.php/mpr/ article/html/1280/>. Accessed: Jun. 15, 2017. doi: 10.5376/ mpr.2014.04.0004.

EISENBRAND, G. et al. Methods of in vitro toxicology. Food and Chemical Toxicology. v.40,p.193-236,2002.Available from: $<$ https://www. sciencedirect.com/science/article/pii/S0278691501001181?via\%3Dihub>. Accessed: Aug. 02, 2017. doi: 10.1016/S0278-6915(01)00118-1.

EZHILARASI P. N. et al. Nanoencapsulation techniques for food bioactive components: a review. Food Bioprocess Technology, v.6, n.3, p.628-647, 2013. Available from: < https://link.springer. com/article/10.1007/s11947-012-0944-0>. Accessed: Dec. 08, 2015. doi: 10.1007/s11947-012-0944-0.

HUANG, C. et al. Measurements of age-related changes of physiological process that predict lifespan of Caenorhabditis elegans. Proceeding of the National Academy of Sciences, v.101, n.21, p.8084-8089, 2004. Available from: < https://www.ncbi.nlm. nih.gov/pmc/articles/PMC419561/>. Accessed: May, 20, 2018. doi: $10.1073 /$ pnas.0400848101.

GONZALEZ-MORAGAS, L. C. elegans as a tool for in vivo nanoparticle assessment. Advances in Colloid and Interface Science, v.219, p.10-26, 2015. Available from: <https://www. sciencedirect.com/science/article/pii/S0001868615000287>. Accessed: Apr. 21, 2018. doi: 10.1016/j.cis.2015.02.001. 
MCCLEMENTS, D. J.; RAO, J. Food-Grade Nanoemulsions: Formulation, Fabrication, Properties, Performance, Biological Fate, and Potential Toxicity. Food Science and Nutrition, v.51, n.4, p.285-330, 2011. Available from: <https://www. tandfonline.com/doi/abs/10.1080/10408398.2011.55955 8? journalCode $=$ bfsn20>. Accessed: Mar. 07, 2015. doi: 10.1080/10408398.2011.559558.

MENDES, L.P. et al. Biodegradable nanoparticles designed for drug delivery: The number of nanoparticles impacts on cytotoxicity. Toxicology in vitro, v.29, p.1268-1274, 2015. Available from: $<$ https://www.sciencedirect.com/science/article/ pii/S0887233314002707?via\%3Dihub>. Accessed: Aug. 17, 2018. doi: 10.1016/j.tiv.2014.12.021.

MIGLIORI, M. L. et al. Circadian rhythms in metabolic variables in Caenorhabditis elegans. Physiology \& Behavior, v.103, n.3-4 p.315-320, 2011. Available from: $<$ https://www.sciencedirect.com/ science/article/abs/pii/S0031938411000527>. Accessed: Mar. 01, 2018. doi: 10.1016/j.physbeh.2011.01.026.

RIDDLE, D. L. et al. Introduction to C. elegans. 2nd. New York: Cold Spring Harbor, 1997.

ROCKENBACH, I.I. et al. Ácidos Fenólicos e atividade antioxidante em fruto de Physalis peruviana L. Alimentos e Nutrição, v.19, n.3, p.271-276, 2008. Available from: <http://www. academia.edu $/ 18733905 / \% \mathrm{C} 3 \% 81$ cidos fen $\% \mathrm{C} 3 \% \mathrm{~B} 31$ icos e atividade_antioxidante_em_fruto_de_Physalis_peruviana_l>. Accessed: Mar. 02, 2014.

SALVIA-TRUJILLO, L. et al. Physicochemical characterization aned antimicrobial activity of food-grade emulsions and nanoemulsions incorporating essential oils. Food Hydrocolloids, v.43, p.547-556, 2015. Available from: $<$ https://www.sciencedirect.
com/science/article/pii/S0268005X14002550>. Accessed: Jan. 15, 2017. doi: 10.1016/j.foodhyd.2014.07.012.

SHEKHAR, C. Lean and mean: Nanoparticle-based delivery improves performance of cancer drugs. Chemistry \& Biology, v.16, p.349-350, 2009. Available from: <https:/www.sciencedirect. com/science/article/pii/S107455210900115X?via\%3Dihub>. Accessed: May, 21, 2017. doi: 10.1016/j.chembiol.2009.04.002.

STEFANELLO, S. T. et al. Protective effects of novel organic selenium compounds against oxidative stress in the nematode Caenorhabditis elegans. Toxicology Reports, v.2, p.961-967, 2015. Available from: $<$ https://www.sciencedirect.com/science/ article/pii/S2214750015300202>. Accessed: Aug. 13, 2018. doi: 10.1016/j.toxrep.2015.06.010.

VELASQUES, K. Co-nanoencapsulation of antimalarial drugs increases their in vitro efficacy against Plasmodium falciparum and decreases their toxicity to Caenorhabditis elegans. European Journal of Pharmaceutical Sciences, v.118, p.1-12, 2018. Available from: $<$ https://www.ncbi.nlm.nih.gov/pubmed/29550283>. Accessed: Jun. 28, 2018. doi: 10.1016/j.ejps.2018.03.014

YOU, Y. J. et al. Insulin, cGMP, and TGF-beta signals regulate food intake and quiescence in C. elegans: a model for satiety. Cell Metabolism, v.7, n.3, p.249-257, 2008. Available from: <https:// www.ncbi.nlm.nih.gov/pmc/articles/PMC3786678/>. Accessed: Sep. 17, 2018. doi: 10.1016/j.cmet.2008.01.005

WANG, J. et al. Recommendation for modifying current cytotoxicity testing standards for biodegradable magnesiumbased materials. Acta Biomaterialia, v.21, p.237-249, 2015. Available from: <https://www.sciencedirect.com/science/article/ pii/S1742706115001828?via\%3Dihub>. Accessed: May, 25, 2018. doi: 10.1016/j.actbio.2015.04.011. 